\title{
EXAMINATION OF THE LEISURE ATTITUDES OF INDIVIDUALS LIVING IN TURKEY FROM AN EAST TO WEST PERSPECTIVE
}

\author{
Süleyman Munusturlar \\ Anadolu University, Eskisehir, Turkey
}

\begin{abstract}
Background. This study aims at examining the leisure attitudes of individuals by comparing eastern and western cities. The study cinvolved 469 individuals who were living within the borders of İstanbul, Ankara, Eskişehir, Van, Tunceli and Hakkari and were selected through convenience sampling. While 257 participants were female, 212 of them were male.

Methods. In the study, Independent Samples $t$-test, which is a parametric test, One Way Variance Analysis (ANOVA) and Kruskal Wallis, which is a non-parametric test, were used in order to determine the independent variables affecting the dependent variable of leisure attitude and its sub-dimensions.

Results. The statistical analyses carried out revealed that the city of residence, the region of residence and education had impact on the leisure attitudes. Individuals living in eastern cities had lower leisure attitude scores than those living in western cities, educational status also was an important variable affecting the leisure attitude in eastern cities.

Conclusion. In conclusion, leisure attitudes of individuals were affected positively and negatively by many variables within the context of limitations and opportunities that principally the geographical region brings along.
\end{abstract}

Keywords: leisure, eastern and western cities, leisure participation.

\section{INTRODUCTION}

$\mathrm{H}$ uman behaviour is one of the main topics that has been the focus of academic studies for many years. Especially within the social sciences, the concepts of motivation and attitude have been called upon to explain how human behaviour emerged and how it developed with other parts of life such as workplace, school, family, health, sports and socialization. Also, the number of studies on leisure attitudes is increasing, with the concept of attitude attracting the interest of scientists. When such studies first emerged, attitude was considered as a psychological process. However, in the following years, the view that this psychological process is completed by a motor harmony became dominant (Allport, 1967). Human behaviour and attitude have always been associated. Attitude refers to a positive or negative assessment statement about objects, people or events (Robbins, 1994). Attitude is an individual's tendencies towards any object, article or idea (IsoAhola, 1980; Uzun \& Sağlam, 2006). Attitude is a psychological structure which has cognitive, affective and behavioural dimensions and appears in the form of acceptance or rejection of a certain person, group, institution or idea (Anderson, 1988). In other words, although there are differing opinions, it is a widely accepted approach that attitude has affective, cognitive and behavioural components (Huang, Chiu, \& Hong, 2016). Attitude to behavior relates to the degree of an individual's positive or negative assessment of behavior/planned behavior (Gonen \& Griberg, 2016; Hilgard \& Atkinson, 1979). In comprehending the concept of attitude, knowing what is not important is as valuable as 
knowing what is. Inappropriately, attitude has been defined as a good or bad feeling or emotion. Rather, it is a sentiment about the goodness or badness of something. It is the behavioural tendency that the individual adopts until the existing opinion changes (Eiser \& van der Pligt, 1988). Although various theoreticians term it differently, attitudes have four functions in social psychology: providing information, adaptation, self-expression and ego protection (Hogg \& Vaughan, 1995). According to social psychology, a direct and simple relation exists between attitude and behaviour. Although attitude and behaviour are mixed in this relation, attitude is essentially different from behaviour and serves to estimate the intention concerning the behaviour (Augostinos, Walker, \& Donaghue, 2006). The main factors affecting leisure attitude are leisure partners, family and past experiences (Siegenthaler \& O'Dell, 2000).

Leisure attitude is a concept which researchers use to explain leisure participation and leisure behaviours, providing information about an individual's willingness and tendency to take part in leisure activities (Ragheb \& Tate, 1993). Attitude consists of three elements, which are cognitive, affective and behavioral (Bagozzi, 1978; Ostrom, 1969). The cognitive element is constituted by the belief, information and experience that a person has towards surrounding stimulants. The affective element consists of positive and negative sentiments that a person has towards the surrounding stimulants and shape the behaviour response of the person towards these stimulants. The behavioural element is related to actions taken by people in line with their sentiments and knowledge (Kraiger, Ford, \& Salas, 1993). In the leisure attitude, the cognitive element contains information and beliefs on such issues related to leisure as health, happiness, making friends, renewal and relaxation. The affective element of leisure is associated with values attributed to and emotions felt about leisure activities as well as feelings experienced following participation in leisure activity, while the behavioural element contains the expression of views and feelings after the participation as well as its impacts on the subsequent participation in leisure activities (Ragheb \& Beard, 1982).

Ragheb and Beard (1982) reported a very weak relationship between cognitive, affective and behavioural leisure attitude and age, sex, income, education and demographic variables. Ragheb and Tate (1993) stated particularly that affective and cognitive leisure attitude had an impact on increasing leisure participation and leisure attitude. Likewise, Mannell and Kleiber (1997) reported that attitudes, beliefs and values concerning leisure affected leisure participation and the outcome obtained from the leisure experience. Teixeira and Freire (2013) stated that leisure attitude is a personal concept containing cognitive, affective and behavioural elements, which increase leisure estimation and subjective wellbeing (happiness). Kim, Sung, Park and Dittmore (2015) reported that positive leisure attitude increased leisure estimation and self-respect while reducing stress and loneliness. In many studies, which have attempted to explain leisure participation in the last 40 years (Davis, Jackson, Kronenfeld, \& Blair, 1984; Hagger, Chatzisarantis, \& Biddle, 2001; Iso-Ahola, 1980), the most important factor affecting leisure behaviour was leisure motivation. Deng, Walker, and Swinnerton (2005) showed that there was a significant relation between leisure motivation and cognitive leisure attitude. Ellis and Witt (1994) reported that leisure attitude was affected by the sentiments of competence and control which were closely associated with the feeling of freedom felt in leisure. We believe that there is a need for research which examines leisure attitude from the perspectives of Western and Eastern cities due to social-cultural inequality by Turkish community. Therefore, this study aims to explore leisure attitudes of individuals living in Eastern and Western regions of Turkey.

\section{METHODS}

Research sample. After excluding the missing data and extreme values from the initial 522 participants surveyed in the study, the sample consisted of 469 people who were selected using a convenience sampling method. 291 of the participants were living in eastern cities and 177 of them were living in western cities. Although there are seven geographical regions in Turkey, the study was restricted to the eastern cities of Van, Hakkari and Tunceli from the eastern and southeastern regions and the western cities of İstanbul, Ankara and Eskişehir from Marmara and Central Anatolia regions in order to obtain a homogeneous sample.

Data collection tools. Two different data collection tools were used. The first was the personal information form developed in order to acquire the demographic information of the participants. The other data collection tool was the Leisure Attitude 
Scale (LAS), which was developed by Ragheb and Beard in 1982 in order to assess leisure attitudes of the participants and was adapted into Turkish by Akgül and Gürbüz (2010). The LAS is a 5-point Likert-type scale and consists of 3 dimensions: cognitive (12 items), affective (12 items) and behavioural (12 items), amounting to 36 items in total. In the study carried out by Akgül and Gürbüz, in adapting the scale into Turkish, Cronbach's Alpha reliability coefficient $(\alpha)$ of the scale was found as .97 while those of the cognitive, affective and behavioural dimensions were found to be .81 , .92 and .91 , respectively. Within the scope of this study, the Cronbach's Alpha reliability coefficient of the scale was .82 , while those of the cognitive, affective and behavioural dimensions were .79, .72 and .83 , respectively. Alpar (2010) stated that the scales with Cronbach's Alpha coefficients ranging between .60 and .79 could be accepted as "quite reliable" and those with Cronbach's Alpha coefficients between .80 and 1.00 could be regarded as "highly reliable". In the light of this information, the Leisure Attitude Scale used in the present study was a reliable data collection tool.

Data collection and analysis. Data were collected from the participants who were selected through convenience sampling method on voluntary basis and were living in İstanbul, Ankara, Eskişehir, Van, Tunceli and Hakkari between February and April, 2016. Missing data and extreme values were excluded from the data set in order to make the research data ready for analysis.
The results of the Levene test for making a decision on the use of parametric and nonparametric tests prior to difference statistics revealed that the variances were homogeneous $(p>.05)$, and the results of Kolmogorov-Smirnov test showed that the groups displayed normal distribution $(p>.05)$. Therefore, a parametric Independent Samples $t$-test and One Way Analysis of Variance (ANOVA) were used to question whether dependent variables differed according to independent variables. Because education, as an independent variable, had both homogeneity and normal distribution problems, a Kruskal Wallis variance analysis test, which is a nonparametric test, was used for this variable.

\section{RESULTS}

As seen in Table 1, 257 of 469 participants were female $(54.8 \%)$ and 212 of them were male $(45.2 \%)$. Sixty participants (12.8\%) were aged 19 and below, 144 (30.7\%) were aged 20-22, $110(23.5 \%)$ were aged 23-25, 50 (10.7\%) were aged 26-30 and 105 (22.4\%) were aged 31 and above. Five of the participants (1.1\%) were illiterate, $27(5.8 \%)$ were primary school graduates, 37 (7.9\%) were secondary school graduates, $78(16.6 \%)$ were high school graduates and $322(68.7 \%)$ were university graduates. The number of residents of the eastern cities of Hakkari, Tunceli and Van were 172 (36.8\%), 92 (19.6\%) and 27 (5.8\%), respectively, while 99 participants (21.1\%) lived in Eskişehir, 37 (7.9\%) in İstanbul and 41 $(8.8 \%)$ in Ankara in the west.

\begin{tabular}{|c|c|c|c|c|c|}
\hline Variable & $f$ & $\%$ & Variable & $f$ & $\%$ \\
\hline Gender & & & Educational Status & & \\
\hline Female & 257 & 54.8 & Illeterate & 5 & 1.1 \\
\hline \multirow[t]{4}{*}{ Male } & 212 & 45.2 & Primary school & 27 & 5.8 \\
\hline & & & Secondary school & 37 & 7.9 \\
\hline & & & High school & 78 & 16.6 \\
\hline & & & University & 23 & 4.4 \\
\hline Age & & & City of residence & & \\
\hline 19 years and below & 60 & 12.8 & Hakkari & 172 & 36.8 \\
\hline 20-22 years & 144 & 30.7 & Tunceli & 92 & 19.6 \\
\hline $23-25$ years & 110 & 23.5 & Van & 27 & 5.8 \\
\hline $26--30$ years & 50 & 10.7 & Ankara & 41 & 8.8 \\
\hline \multirow[t]{2}{*}{31 years and above } & 105 & 22.4 & İstanbul & 37 & 7.9 \\
\hline & & & Eskişehir & 99 & 21.1 \\
\hline
\end{tabular}

Table 1. Demographic features of the sample 
Table 2 shows the arithmetic means and standard deviation values of the participants in the leisure attitude $(3.78, S D=0.64)$ as well as those of the cognitive $(3.92, S D=0.69)$, affective $(3.84$, $S D=0.71)$ and behavioural $(3.56, S D=0.77)$ attitude dimensions. When means concerning the leisure attitude were evaluated, the cognitive attitude had a considerably higher score than the other attitude dimensions.

An Independent Samples $t$-test was carried out to determine whether the scores of the participants in the leisure attitude dimensions differed by gender, but a statistically significant difference could not be found between the groups.

While the ANOVA was conducted in order to detect whether the scores of the participants in the leisure attitude and leisure attitude dimensions differed by age, a Tukey Post Hoc test was employed to determine the groups among which there were differences (Table 3). Statistically significant differences were detected among the groups by the variable of age in the total leisure attitude score $\left(F_{(4,464)}=4.015 ; p<.01\right)$ as well as in the cognitive attitude $\left(F_{(4,464)}=3.095 ; p<.01\right)$, affective attitude $\left(F_{(4,464)}=4.419 ; p<.05\right)$ and behavioural attitude $\left(F_{(4,464)}=2.784 ; p<.01\right)$ dimensions.

The differences in the means concerning the leisure attitude were among group 5 and groups 2 and 3. The leisure attitude scores of the participants aged 20-22 (group 2) and 23-25 (group 3) were higher than those of the participants at the age of 31 and above (group 5). The significant difference in the cognitive attitude scores could be attributed to higher means of the individuals aged 20-22 (group 2) when compared to the individuals at the age of 31 and above (group 5). In the affective attitude dimension, a statistically significant difference resulting from the lower means of the individuals at the age of 31 and above when compared to both individuals at the age of 20-22 (group 2) and 23-25 (group 3) was observed. Likewise, in the behavioural dimension, the significant difference originated from lower means of the individuals aged 31 and above (group 5) than those of the individuals aged 20-22 (group 2) and 19 and below (group 1). The means of the individuals aged 31 and above are lower than the means of the other age groups in all leisure attitude dimensions. This results can be interpreted as individuals aged 31 and above have neither enough cognitive information on leisure and lack of emotional interaction on leisure nor participation in leisure activities compared with other age groups.

The Kruskal-Wallis test was employed in order to detect whether the scores of the participants in the leisure attitude and leisure attitude dimensions by the variable of education since parametric test conditions were met. The analysis revealed statistically significant differences among the groups by the variable of education in the total

Table 2. Leisure attitude levels of the participants

\begin{tabular}{|l|c|c|}
\hline \multicolumn{1}{|c|}{ Levels } & Points & SD \\
\hline Leisure attitude & 3.78 & 0.64 \\
\hline Cognitive & 3.92 & 0.69 \\
\hline Affective & 3.84 & 0.71 \\
\hline Behavioural & 3.56 & 0.77 \\
\hline$n=458 ; 1$ = Strongly disagree, 5 = Strongly agree \\
\hline
\end{tabular}

Table 3. Leisure Attitude Levels of the Participants by the Variable of Age

\begin{tabular}{|c|c|c|c|c|c|c|c|c|c|c|c|c|}
\hline & \multicolumn{2}{|c|}{$\begin{array}{c}19 \text { age and } \\
\text { below (Group 1) }\end{array}$} & \multicolumn{2}{|c|}{$\begin{array}{l}\text { 20-22 age } \\
\text { (Group 2) }\end{array}$} & \multicolumn{2}{|c|}{$\begin{array}{l}\text { 23-25 age } \\
\text { (Group 3) }\end{array}$} & \multicolumn{2}{|c|}{$\begin{array}{l}\text { 26-30 age } \\
\text { (Group 4) }\end{array}$} & \multicolumn{2}{|c|}{$\begin{array}{l}31 \text { age and above } \\
\text { (Group 5) }\end{array}$} & \multirow[b]{2}{*}{$F$} & \multirow[b]{2}{*}{$p$} \\
\hline & & $s d$ & & $s d$ & & $s d$ & & $s d$ & & $s d$ & & \\
\hline Leisure attitude & 3.77 & .65 & 3.87 & .53 & 3.86 & .61 & 3.74 & .70 & 3.57 & .73 & 4.015 & $.01 *$ \\
\hline Cognitive & 3.92 & .62 & 4.03 & .53 & 3.99 & .63 & 3.80 & .77 & 3.75 & .78 & 3,095 & $.00 * *$ \\
\hline Affective & 3.79 & .73 & 3.97 & .62 & 3.93 & .67 & 3.83 & .72 & 3.62 & .80 & 4.419 & $.02 *$ \\
\hline Behavioural & 3.60 & .80 & 3.61 & .67 & 3.67 & .74 & 3.61 & .85 & 3.35 & .86 & 2.784 & $.00 * *$ \\
\hline
\end{tabular}

Note. $* p<.05, * * p<.01$. 
leisure attitude score $\left(F_{(4,464)}=4.015 ; p<.01\right)$ as well as in the cognitive attitude $\left(F_{(4,464)}=3.095\right.$; $p<.01)$, affective attitude $\left(F_{(4,464)}=4.419 ; p<.05\right)$ and behavioural attitude $\left(F_{(4,464)}=2.784 ; p<.01\right)$ dimensions. Bonferroni Correction was used in order to determine the groups among which these significant differences existed (Table 4).

When the differences between the scores in the leisure attitude and its dimensions according to the educational status were examined, a statistically significant difference was detected in the total leisure attitude scores among the university graduates and the graduates of primary schools, secondary schools and high schools in favour of those having had university education. Similarly, there were significant differences in the cognitive attitude scores among the university graduates and primary school graduates, in the affective attitude scores among the university graduates and graduates of primary and secondary schools, and in the behavioral attitude scores among the university graduates and illiterate individuals and primary school graduates in favor of the university graduates. In this study, higher education, at the university level in particular, positively affected the leisure attitude.

An Independent Samples $t$-test was carried out to detect whether the scores of the participants in the leisure attitude and its dimensions differed by the variable of the region of residence (east-west) with significant differences observed among the groups. These significant differences were in favour of the individuals living in the western cities in the total leisure attitude scores $(t=-7.940, p=.00)$ as well as in the cognitive $(t=-7.695, p=.00)$, affective $(t=-6.494, p=.00)$ and behavioural $(t=-6.579$, $p=.00$ ) attitude scores (Table 5). This results can be interpreted as individuals who live in the Eastern region of Turkey have neither enough cognitive information on leisure and lack of emotional

Table 4. Leisure attitude levels of the participants by the variable of educational status

\begin{tabular}{|c|c|c|c|c|c|c|c|c|c|c|c|c|c|c|c|c|c|}
\hline & \multicolumn{3}{|c|}{$\begin{array}{l}\text { Illeterate } \\
\text { Group 1) }\end{array}$} & \multicolumn{3}{|c|}{$\begin{array}{l}\text { Primary School } \\
\text { (Group 2) }\end{array}$} & \multicolumn{3}{|c|}{$\begin{array}{c}\text { Secondary School } \\
\text { (Group 3) }\end{array}$} & \multicolumn{3}{|c|}{$\begin{array}{c}\text { High School } \\
\text { (Group 4) }\end{array}$} & \multicolumn{3}{|c|}{$\begin{array}{l}\text { University } \\
\text { (Group 5) }\end{array}$} & \multirow[b]{2}{*}{$\mathbf{X}^{2}$} & \multirow[b]{2}{*}{$p$} \\
\hline & Med & $\begin{array}{l}\text { Min } \\
\text { Max }\end{array}$ & & Med & $\begin{array}{l}\text { Min } \\
\text { Max }\end{array}$ & & Med & $\begin{array}{l}\text { Min } \\
\text { Max }\end{array}$ & & Med & $\begin{array}{l}\text { Min } \\
\text { Max }\end{array}$ & & Med & $\begin{array}{l}\text { Min } \\
\text { Max }\end{array}$ & & & \\
\hline \multirow{2}{*}{$\begin{array}{l}\text { Leisure } \\
\text { attitude }\end{array}$} & \multirow{2}{*}{3.91} & 2.75 & \multirow{2}{*}{3.83} & \multirow{2}{*}{3.61} & 1.61 & \multirow{2}{*}{3.44} & \multirow{2}{*}{3.55} & 1.75 & \multirow{2}{*}{3.53} & \multirow{2}{*}{3.66} & 1.92 & \multirow{2}{*}{3.55} & \multirow{2}{*}{3.91} & 2.06 & \multirow{2}{*}{3.89} & \multirow{2}{*}{4.015} & \multirow{2}{*}{$.01^{*}$} \\
\hline & & 4.75 & & & 5.00 & & & 4.64 & & & 4.75 & & & 5.00 & & & \\
\hline \multirow{2}{*}{ Cognitive } & \multirow{2}{*}{3.58} & 1.92 & \multirow{2}{*}{3.63} & \multirow{2}{*}{3.83} & 1.50 & \multirow{2}{*}{3.77} & \multirow{2}{*}{3.66} & 2.25 & \multirow{2}{*}{3.70} & \multirow{2}{*}{3.91} & 1.50 & \multirow{2}{*}{3.74} & \multirow{2}{*}{4.08} & 1.50 & \multirow{2}{*}{3.98} & \multirow{2}{*}{3.095} & \multirow{2}{*}{$.01 *$} \\
\hline & & 5.00 & & & 4.32 & & & 5.00 & & & 5.00 & & & 5.00 & & & \\
\hline \multirow{2}{*}{ Affective } & \multirow{2}{*}{3.66} & 2.50 & & & 1.42 & & & 1.25 & & & 1.92 & & & 1.83 & & & \\
\hline & & 5.00 & 3.81 & 3.66 & 5.00 & 3.44 & 3.58 & 4.83 & 3.53 & 3.10 & 5.00 & 3.02 & 4.00 & 5.00 & 3.08 & 4.419 & $.02^{\circ}$ \\
\hline & & 2.42 & & & 1.50 & & & 1.08 & & & 1.75 & & 270 & 1.33 & & & $01 *$ \\
\hline Benavioural & 4.50 & 5,00 & 4.05 & 3.40 & 5,00 & 3.12 & 3.41 & 4,67 & 3.35 & 3.53 & 4,75 & 3.50 & 3.10 & 5,00 & 3.89 & 2.184 & $.01^{*}$ \\
\hline
\end{tabular}

Note. $* p<.05, \quad * * p<.01$.

Table 5. Leisure attitude levels of the participants by the variable of the region of residence (East-West)

\begin{tabular}{|c|c|c|c|c|c|c|}
\hline Dependent Variable & Region of Residence & $n$ & & $S D$ & $t$ & $p$ \\
\hline \multirow{2}{*}{ Leisure Attitude } & East & 292 & 3.6 & 0.64 & \multirow{2}{*}{-7.94} & \multirow{2}{*}{$.00 * *$} \\
\hline & West & 177 & 4.06 & 0.53 & & \\
\hline \multirow{2}{*}{ Cognitive } & East & 292 & 3.74 & 0.72 & \multirow{2}{*}{-7.7} & \multirow{2}{*}{$.00 * *$} \\
\hline & West & 177 & 4.22 & 0.53 & & \\
\hline \multirow{2}{*}{ Affective } & East & 292 & 3.68 & 0.07 & \multirow{2}{*}{-6.49} & \multirow{2}{*}{$.00 * *$} \\
\hline & West & 177 & 4.11 & 0.59 & & \\
\hline \multirow{2}{*}{ Behavioural } & East & 292 & 3.39 & 0.79 & \multirow{2}{*}{-6.58} & \multirow{2}{*}{$.00 * *$} \\
\hline & West & 177 & 3.85 & 0.65 & & \\
\hline
\end{tabular}

Note. $* p<.05, \quad * * p<.01$ 
interaction on leisure nor participation in leisure activities when compared with individuals who live in the Western region of Turkey.

According to the results of the One Way Variance Analysis (ANOVA) which was used to determine whether the scores of the participants in the leisure attitude and its dimensions by the variable of the city of residence. there were statistically significant differences among the groups by the variable of the city of residence in terms of both total leisure attitude score $\left(F_{(5,463)}=\right.$ $22.989, p<.01)$ and cognitive attitude $\left(F_{(5,463)}=\right.$ $19.640, p<.01)$. affective attitude $\left(F_{(5,463)}=16.507\right.$, $p<.05)$ and behavioural attitude $\left(\left(F_{(5,463)}=15.889\right.\right.$, $p<.01)$ dimensions. The results of the Post Hoc (Tukey) test revealed that there was a significant difference between the leisure attitude. cognitive attitude. affective attitude and behavioural attitude score means of the residents of Hakkari and those of the residents of Tunceli, Eskişehir, İstanbul and Ankara against the former. Additionally, a significant difference was detected between Van and İstanbul in terms of leisure attitude while the behavioral attitude scores differed significantly between the residents of Van and İstanbul once again, Van and Ankara and Van and Eskişehir against the residents of Van. In other words, leisure attitudes of those living in Hakkari are lower than those of the residents of western cities as well as Tunceli, whereas leisure attitudes of the residents of Van are lower than those of the individuals living in western cities (Table 6).

The leisure attitude scores and dimension scores of the participants living in eastern and western cities also were examined separately. Statistical analyses showed that the cognitive, affective, behavioural attitude and leisure attitude scores of the residents of eastern cities were not affected by the independent variables of sex, education and age. However, the leisure attitude and dimension scores of the individuals living in eastern cities differed significantly by the city of residence (Table 7).

Table 6. Leisure Attitude Levels of the Participants by the Variable of the City of Residence

\begin{tabular}{|c|c|c|c|c|c|c|c|c|c|c|c|c|c|c|}
\hline & \multicolumn{2}{|c|}{$\begin{array}{c}\text { Hakkari } \\
\text { (Group 1) }\end{array}$} & \multicolumn{2}{|c|}{$\begin{array}{c}\text { Tunceli } \\
\text { (Group 2) }\end{array}$} & \multicolumn{2}{|c|}{$\begin{array}{l}\text { Eskişehir } \\
\text { (Group 3) }\end{array}$} & \multicolumn{2}{|c|}{$\begin{array}{c}\text { Van } \\
\text { (Group 4) }\end{array}$} & \multicolumn{2}{|c|}{$\begin{array}{c}\text { İstanbul } \\
\text { (Group 5) }\end{array}$} & \multicolumn{2}{|c|}{$\begin{array}{c}\text { Ankara } \\
\text { (Group 6) }\end{array}$} & \multirow[b]{2}{*}{$F$} & \multirow[b]{2}{*}{$p$} \\
\hline & & $S D$ & & $S D$ & & $S D$ & & $S D$ & & $S D$ & & $S D$ & & \\
\hline $\begin{array}{l}\text { Leisure } \\
\text { attitude }\end{array}$ & 3.43 & .67 & 3.92 & .48 & 4.02 & .56 & 3.67 & .43 & 4.25 & .49 & 4.18 & .50 & 22.989 & $.00 * *$ \\
\hline Cognitive & 3.56 & .75 & 4.02 & .59 & 4.20 & .56 & 3.90 & .50 & 4.07 & .47 & 4.33 & .49 & 19.640 & $.00 * *$ \\
\hline Affective & 3.50 & .76 & 4.00 & .59 & 4.08 & .61 & 3.82 & .55 & 3.82 & .57 & 4.20 & .56 & 16.507 & $.00 * *$ \\
\hline Behavioural & 3.22 & .84 & 3.73 & .62 & 3.79 & .70 & 3.29 & .55 & 4.02 & .54 & 4.02 & .63 & 15,889 & $.00^{* *}$ \\
\hline
\end{tabular}

Note. $* p<.05, \quad * * p<.01$.

Table 7. Leisure attitude levels of individuals living in eastern cities by the variable of the city of residence

\begin{tabular}{|c|c|c|c|c|c|c|c|c|}
\hline & \multicolumn{2}{|c|}{ Hakkari (Group 1) } & \multicolumn{2}{|c|}{ Tunceli Group 2) } & \multicolumn{2}{|c|}{ Van (Group 3) } & \multirow[b]{2}{*}{$\boldsymbol{F}$} & \multirow[b]{2}{*}{$p$} \\
\hline & & $s d$ & & $s d$ & & $s d$ & & \\
\hline $\begin{array}{l}\text { Leisure } \\
\text { attitude }\end{array}$ & 3.43 & .67 & 3.92 & .48 & 4.02 & .56 & 20.138 & $.00 * *$ \\
\hline Cognitive & 3.56 & .75 & 4.02 & .59 & 4.20 & .56 & 6.748 & $.00 * *$ \\
\hline Affective & 3.50 & .76 & 4.00 & .59 & 4.08 & .61 & 7.911 & $.00 * *$ \\
\hline Behavioural & 3.22 & .84 & 3.73 & .62 & 3.79 & .70 & 13.837 & $.00 * *$ \\
\hline
\end{tabular}

Note. $* p<.05, \quad * * p<.01$ 
The results of the Post Hoc (Tukey) test showed that the residents of Tunceli had higher means in the leisure attitude and affective attitude scores than the residents of Hakkari, while residents of both Van and Tunceli had higher means in the cognitive and behavioural attitude scores when compared to the residents of Hakkari (Table 7).

As a result of the statistical analyses, it was observed that cognitive, affective, behavioral and total attitude scores of participants who lived in western provinces were not affected by the independent variables of gender and province. On the other hand, it was observed that the scores obtained by individuals who lived in western provinces from the leisure attitude and its lower dimensions were significantly different according to the variables of educational background (Table 8) and age (Table 9).

The Kruskal-Wallis test was used in order to determine whether the scores of the participants living in western cities in the leisure attitude and its dimension differed by the variable of education since parametric test conditions were not met. At the end of the statistical analysis, statistically significant differences were observed among the groups in the cognitive attitude $\left(F_{(4,173)}=3.095\right.$, $p<.01)$ and affective attitude $\left(F_{(4,173)}=4.419\right.$, $p<.05)$ dimension scores by the variable of education. Bonferroni Correction was used in order to detect the groups among which significant differences existed (Table 8).

When the differences between the leisure attitude scores and dimension scores of the participants living in western cities by the variable of education were examined, significant differences were observed between university graduates and graduates of primary and secondary schools and between graduates of primary schools and graduates of secondary schools in the cognitive and affective attitude scores. The cognitive and affective attitude scores decreased as the level of education decreased (Table 8).

The ANOVA was carried out to determine whether the scores of the participants living in western cities related to leisure attitude and its dimensions differed by the variable of age while Tukey Post Hoc test was made to detect the groups among which differences existed (Table 9). Statistically significant differences were observed among the groups by the variable of age in the total leisure time score $\left(F_{(4,173)}=4.691, p<.01\right)$, cognitive attitude dimension $\left(F_{(4,173)}=2,224\right.$, $p<.01)$, affective attitude dimension $\left(F_{(4,173)}=\right.$ $5.029, p<.05)$ and behavioural attitude dimension $\left(F_{(4,173)}=4.481, p<.01\right)$.

The differences in the means concerning the leisure attitude are among group 5, group 2 and group 3 . The study showed that the leisure attitude scores of the individuals aged 20-22 (group 2) and 23-25 (group 3) are higher than those of the individuals at the age of 31 and above (group 5). In the behavioural attitude dimension, significant difference results from the fact that individuals aged 31 and above (group 5) have lower mean values than the individuals aged 20-22 (group 2) and 23-25 (group 3). In the behavioural attitude dimension, the significant difference stems from the mean values of the individuals aged 31 and above

Table 8. Leisure attitude levels of the individuals living in western cities by the variable of educational status

\begin{tabular}{|c|c|c|c|c|c|c|c|c|c|c|c|c|c|c|}
\hline & \multicolumn{3}{|c|}{$\begin{array}{l}\text { Illeterate } \\
\text { (Group 1) }\end{array}$} & \multicolumn{3}{|c|}{$\begin{array}{l}\text { Primary School } \\
\text { (Group 2) }\end{array}$} & \multicolumn{3}{|c|}{$\begin{array}{l}\text { Secondary School } \\
\text { (Group 3) }\end{array}$} & \multicolumn{3}{|c|}{$\begin{array}{l}\text { High School } \\
\text { (Group 4) }\end{array}$} & \multirow[b]{2}{*}{$\mathbf{X}^{2}$} & \multirow[b]{2}{*}{$p$} \\
\hline & Med & $\begin{array}{l}\text { Min } \\
\max \end{array}$ & & Med & $\begin{array}{l}\text { Min } \\
\max \end{array}$ & & Med & $\begin{array}{l}\text { Min } \\
\max \end{array}$ & & Med & $\begin{array}{l}\text { Min } \\
\max \end{array}$ & & & \\
\hline \multirow{2}{*}{$\begin{array}{l}\text { Leisure } \\
\text { Attitude }\end{array}$} & \multirow{2}{*}{3.59} & 1.61 & \multirow{2}{*}{3.32} & \multirow{2}{*}{3.55} & 3.56 & \multirow{2}{*}{3.86} & \multirow{2}{*}{3.88} & 3.00 & \multirow{2}{*}{3.82} & \multirow{2}{*}{4.05} & 2.72 & \multirow{2}{*}{4.11} & \multirow{2}{*}{3.029} & \multirow{2}{*}{.47} \\
\hline & & 4.22 & & & 4.47 & & & 4.53 & & & 5.00 & & & \\
\hline \multirow{2}{*}{ Cognitive } & \multirow{2}{*}{3.87} & 1.50 & \multirow{2}{*}{3.58} & \multirow{2}{*}{4.41} & 4.42 & \multirow{2}{*}{4.61} & \multirow{2}{*}{3.83} & 3.50 & \multirow{2}{*}{3.98} & \multirow{2}{*}{4.25} & 3.00 & \multirow{2}{*}{4.25} & \multirow{2}{*}{2.098} & \multirow{2}{*}{$.01 *$} \\
\hline & & 4.25 & & & 5.00 & & & 4.58 & & & 5.00 & & & \\
\hline \multirow{2}{*}{ Affective } & \multirow{2}{*}{3.50} & 1.83 & \multirow{2}{*}{3.25} & \multirow{2}{*}{3.25} & 3.25 & \multirow{2}{*}{3.72} & \multirow{2}{*}{3.91} & 3.00 & \multirow{2}{*}{3.79} & \multirow{2}{*}{4.08} & 2.67 & \multirow{2}{*}{4.17} & & \\
\hline & & 4.08 & & & 4.67 & & & 4.92 & & & 5.00 & & 4.856 & $.01^{*}$ \\
\hline & 341 & 1.50 & 313 & & 3.00 & & & 2.50 & & & 2.33 & & & \\
\hline Behavioural & 3.41 & 4,33 & 3.13 & 3.00 & 3,75 & 3.25 & 3.91 & 4,75 & 3.69 & 4.08 & 5,00 & 3.90 & 1.998 & .13 \\
\hline
\end{tabular}

Note. $* p<.05, \quad * * p<.01$ 
Table 9. Leisure attitude levels of Individuals living in western cities by the variable of age

\begin{tabular}{|c|c|c|c|c|c|c|c|c|c|c|c|c|}
\hline & \multicolumn{2}{|c|}{$\begin{array}{l}19 \text { age and } \\
\text { below } \\
\text { (Group 1) }\end{array}$} & \multicolumn{2}{|c|}{$\begin{array}{l}\text { 20-22 age } \\
\text { (Group 2) }\end{array}$} & \multicolumn{2}{|c|}{$\begin{array}{l}\text { 23-25 age } \\
\text { (Group 3) }\end{array}$} & \multicolumn{2}{|c|}{$\begin{array}{l}\text { 26-30 age } \\
\text { (Group 4) }\end{array}$} & \multicolumn{2}{|c|}{$\begin{array}{l}31 \text { age and } \\
\text { above } \\
\text { (Group 5) }\end{array}$} & \multirow[b]{2}{*}{$F$} & \multirow[b]{2}{*}{$p$} \\
\hline & & $s d$ & & sd & & $s d$ & & $s d$ & & sd & & \\
\hline Leisure attitude & 4.20 & .60 & 4.08 & .41 & 4.11 & .52 & 4.11 & .57 & 3.50 & .69 & 4.691 & $.01 *$ \\
\hline Cognitive & 4.32 & .51 & 4.23 & .46 & 4.25 & .49 & 4.20 & .53 & 3.83 & .81 & 2,224 & .06 \\
\hline Affective & 4.20 & .67 & 4.17 & .51 & 4.13 & .56 & 4.20 & .53 & 3.46 & .69 & 5.029 & $.00 * *$ \\
\hline Behavioural & 4.08 & .75 & 3.84 & .51 & 3.94 & .66 & 3.85 & .70 & 3.22 & .82 & 4.481 & $.00 * *$ \\
\hline
\end{tabular}

Note. $* p<.05, \quad * * p<.01$.

(group 5) being lower than the mean values of the individuals aged 23-25 (group 3), 20-22 (group 2) and 19 and below (group 1). In all leisure attitude dimensions, leisure attitude mean scores of the individuals at the age of 31 and above from western cities are lower than those of the individuals of the other age groups.

\section{DISCUSSION}

When the results of the study are considered, the first point to be examined and emphasized is certainly that leisure attitude differs by the region of residence. The scores of the individuals living in western cities regarding leisure attitude and its dimensions are higher than those of the individuals living in the eastern cities. Many studies, which have been carried out so far, emphasize that geographical region is an important variable affecting the leisure attitude. Individuals living in the American continent have higher cognitive, affective and behavioural attitude scores than those living in the Asian continent (Deng et al., 2005; Walker, Jackson, \& Deng, 2007a; Walker, Deng, \& Chapman, 2007b). On the other hand, Akgül (2011) reported that whether people living in Ankara and London reside in rural, urban or metropolitan regions have not affected their leisure attitudes but mass media might have influenced them. The results of the present study show that the city of residence has caused differentiation in the leisure attitudes even among the individuals living in different eastern cities. While leisure attitude scores do not differ from one city to another in the western cities, the scores of the residents of Tunceli and Van are clearly higher than those of the individuals living in Hakkari.
This finding can be attributed to the differing educational successes of the cities. According to the data of the Turkish Statistical Institution for the year 2016 (TUIK, 2016), Hakkari ranks last in education while Tunceli ranks first. This finding can also be the reason of differentiation of leisure attitude scores both in the general evaluation and separate evaluations on western and eastern cities. The results of the present study show that groups with higher levels of education have higher leisure attitude scores when compared to those with lower levels of education. On the other hand, bearing in mind that availability of geographical conditions of East region cities for outdoor sports, individuals living in East can be motivated to do outdoor recreational activities which proofed social and physical benefits such as such as orienteering (Güzel, Yıldız, Çetinöz, \& Beşikçi, 2016), rock climbing (Gallotta \& Emerenziani, 2015), skiing (Müller et al., 2011) and kayaking (Loomis, 2016). In this way favored aspects of region can be used to increase leisure attitude.

Another striking finding of this study is that the age of individuals affects leisure attitudes. When two regions are considered together and western cities are taken as basis, age affects leisure attitude. On the other hand, age is not a variable affecting leisure attitudes of the individuals living in eastern cities.

This study shows that individuals aged 31 and above have lower leisure attitude scores. Beggs, Kleparski, Elkins, and Hurd (2014) reported that individuals at the age of 18-24, who take advantage of leisure participation especially for personal development, have high motivation levels while the individuals aged 25-34, who exert effort in various aspects of life, have low motivation levels, and 
leisure attitudes of these groups are affected by this situation.

In this study, it was concluded from both general analysis and the analysis on the regions that leisure attitudes were not affected by sex. However, the study conducted by Ragheb and Beard (1982) on leisure attitude indicates that men have higher leisure attitude scores. On the other hand, some studies demonstrate that women have higher leisure motivation than men (Beggs et al., 2014; Fortier, Vallerand, Briere, \& Provencher,1995). In agreement with these findings, Pala, Biner, Öncen, and Kargün (2015) expressed in their study that leisure attitude was not affected by sex, while Karunaanithy and Karunanithy (2014) reported that the impact of sex on leisure participation and leisure attitude cannot be ignored.

Most of the findings of this research can be explained on the basis of the leisure constraints. The evaluation of two regions together contributed to the finding that education level, city of residence and region of residence affected the leisure attitude. The leisure attitude is affected by education and age in western cities, while the city of residence affects the leisure attitude in eastern cities. Godbey, Crawford and Shen (2010) consider age and education as internal constraints and reports that the geographical region of residence should be regarded as an external constraint. External constraints are the factors affecting leisure participation and behaviour even though the internal constraints are overcome (Kim \& Trail, 2010; Kim, 2009). In other words, even though such obstacles as financial difficulties or educational status are eliminated in eastern cities, structural constraints like opportunities and diversity that the region creates can influence the leisure attitudes of the individuals. Many studies conducted so far (Demirel \& Harmandar, 2009; Gratton, 2000; Juniu, 2009; Kim, 2009 ) have revealed that socioeconomic factors directly affect leisure behaviour.

Chiu and Kayat (2010) reported that motivation has a strong direct impact on leisure attitude and participation in physical leisure activities. Other studies conducted on leisure motivation and leisure attitude (Chih Mou Hsieh, 1998; Chiu, 2009; Ragheb \& Tate, 1993; Watson; 1996) also revealed that leisure motivation is a variable affecting the leisure attitude.

When the results obtained from the LAS are examined, the cognitive attitude scores stand out while the behavioural dimension has a lower score than the other attitude dimensions. The study conducted by Ashby, Kottmari, and DeGraff (1999) on university students presented similar findings and shows parallelism with the findings of the present study. In the study carried out by Siegenthaler and O'Dell (2000), the mean score concerning the behavioural attitudes of the university students was lower than the mean scores of the other attitude dimensions. The affective dimension had the highest attitude score instead of the cognitive dimension. This finding can be interpreted to mean that although people have awareness concerning leisure and its use, this awareness is not transformed into leisure behaviour to the same extent.

\section{CONCLUSION}

As a conclusion, the findings of the present study, which examined the leisure attitude from the perspective of individuals living in eastern and western cities, shows that the region of residence has an impact on the leisure attitude. It also indicates that, along with the region of residence, such related variables as the city of residence and education status affect the leisure attitude. Therefore, the leisure attitude is influenced by the region of residence, city of residence, education and age. In the light of such results, it can be stated that individuals live in East region of Turkey have leisure inequality which caused by economic, social and cultural differences of region when they are compared with individuals live in East region of Turkey. This determination is a conclusion of very high concern which should be considered by government, voluntary organizations and market system service providers.

Limitations and Recommendations. This study is restricted to the individuals who live in İstanbul, Ankara, Eskişehir, Van, Tunceli and Hakkari and were selected through convenience sampling method. Also, regional division was made only on the basis of west and east. In future studies, a broader sample, constituted through probabilistic sampling methods and with the potential of representing the seven geographical regions, is recommended. It is recommended that population distribution should be considered according cities because it is one of the limitation of this study. It is also recommended that the relations of the leisure attitude to different independent variables are considered and tested using structural models to be developed. 


\section{REFERENCES}

Akgül, B. (2011). Farkl kültürlerdeki bireylerin boş zaman aktivitelerine yönelik tutumlarının değerlendirilmesi: Ankara- Londra örneği, Gazi Üniversitesi, Sağlık Bilimleri Enstitüsü Beden Eğitimi ve Spor Anabilim Dalı, Yayınlanmamış Doktora Tezi, Ankara.

Akgül, B. M., \& ve Gürbüz, B. (2010). Boş Zaman Tutum Ölçeği: Geçerlik ve Güvenirlik Çalışması. 11. Uluslar arası Spor Bilimleri Kongresi, Antalya.

Allport, G. (1967). Attitudes. In M. Fishebin (Ed.), Readings in attitude theory and measurement. New York: John Wiley and Sons.

Alpar, R. (2010). Uygulamalı çok değişkenli istatistiksel yöntemler. Detay Yayıncılık, Ankara.

Anderson, L. W. (1988). Attitudes and their measurement. In J. P. Keeves (Ed.), Educational research, methodology and measurement: An international handbook. New York: Pergamon Press.

Ashby, J. S., Kottmari, T., \& DeGraaf, D. (1999). Leisure satisfaction and attitudes of perfectionists: implications for therapeutic recreation professionals. Therapeutic Recreation Journal, 2, 142-151.

Augostinos, M., Walker, I. \& Donaghue, N. (2006). Social cognition. Sage: London.

Bagozzi, R. P. (1978). The construct validity of the affective, behavioral, and cognitive components of attitude by analysis of covariance structures. Multivariate Behavioral Research, 13(1), 9-31.

Beggs, B., Kleparski, T., Elkins, D., \& Hurd, A. (2014). Leisure motivation of older adults in relation to other adult life stages. Activities, Adaptation \& Aging, 38(3), 175-187.

Chih-Mou Hsieh. (1998). Leisure attitudes, motivation, participation, and satisfaction: Test on a model of leisure behaviour. Unpublished doctoral thesis, Indiana University.

Chiu, L. K., \& Kayat, K. (2010). Psychological determinants of leisure time physical activity participation among public university students in Malaysia. Ajtlhe, 2(2), 33-45.

Chiu, L. K. (2009). University students' attitude, selfefficacy and motivation regarding leisure time physical participation. Jurnal Pendidik dan Pendidikan, Jil. 24, $1-15$.

Davis, K. E., Jackson, K. L., Kronenfeld, J. J., \& Blair, S. N. (1984). Intent to participation in worksite health promotion activities: A model of risk factors and psycholosocial variables. Health Education Quarterly, 11, 361-377.

Demirel, M., \& Harmandar, D. (2009). Üniversite öğrencilerinin rekreasyonel etkinliklere katılımlarında engel oluşturabilecek faktörlerin belirlenmesi. Uluslararasi İnsan Bilimleri Dergisi, 6(1), 839-846.

Deng, J., Walker, G. J., \& Swinnerton, G. (2005). Leisure attitudes: A comparison between Chinese in Canada and Anglo-Canadians. Leisure/Loisir, 29, 239-273.
Eiser, J. R., \& van der Pligt, J. (1988). Attitudes and decisions. In P. Herriot (Ed.), New essential psychology. New York: Routledge.

Ellis, G. D., \& Witt, P. A. (1994). Perceived freedom in leisure and satisfaction: Exploring the factor structure of the perceived freedom components of the leisure diagnostic battery. Leisure Sciences, 16, 259-270.

Fortier, M. S., Vallerand, R. J., Briere, N. M., \& Provencher, P. J. (1995). Competitive and recreational sport structures and gender: a test of their relationship with sport motivation. International Journal of Sport Psychology, 26, 24-39.

Gallotta, M. C. \& Emerenziani, C. P. (2015). Psychophysical benefits of rock-climbing activity. Perceptual \& Motor Skills: Exercise \& Sport, 121, 3, 675-689.

Godbey, G., Crawford, D., \& Shen, S. (2010). Assessing hierarchical leisure constraints theory after two decades. Journal of Leisure Research, 42(1), 111-134.

Gonen, A., \& Griberg, K. (2016). Academic students' attitudes toward students with learning disabilities. Journal of Education and Training Studies, 4(9), 240-246.

Gratton, C. (2000). Economics of sport and recreation. London, U. K.: Sport Press.

Güzel, P., Yıldız, K., Çetinöz, F. \& Beşikçi, T. (2016). Investigating The Impact of Outdoor Camp on Athletes: Orienteering Example. 14th International Sport Sciences Congress, $01^{\text {st }}-04$ th November, Belek-Antalya (p. 298).

Hagger, M. S., Chatzisarantis, N., \& Biddle, S. J. H. (2001). The influence of self efficacy and past behaviour on the physical activity intentions of young people. Journal of Sport Science, 19, 711-725. doi: 10.1007/ s10212-012-0118-5

Hilgard, E. R., \& Atkinson, R. C. (1979). Introduction to psychology. Australia: Harcourt Publishers Group Pty. Ltd.

Hogg, M. A., \& Vaughan, G. M. (1995). Social psychology: An introduction. London: Prentice Hall/ Harvester Wheatsheaf.

Huang, N. T. N., Chiu, L. J., \& Hong, J. C. (2016). Relationship among students' problem-solving attitude, perceived value, behavioral attitude, and intention to participate in a science and technology contest. International Journal of Science and Mathematic Education, 14:1419-1435. do1:10.1007/s10763-015-9665-y

Iso-Ahola, S. E. (1980). The social psychology of leisure and recreation. Dubuque, IA: Brown.

Juniu, S. (2009). The transformation of leisure. Leisure/ Loisir, 33(2), 463-478.

Karunaanithy K, \& Karunanithy M. (2014). Leisure activities and attitudes of advanced level students: a study based on urban schools in Trincomalee District. European Journal of Business and Management, 6(7).

Kim, J. (2009). Three-factor model and pyramid model of leisure constraints. Journal of Travel and Tourism Research, 123-138. 
Kim, S., Sung, J., Park, J., \& Dittmore, S. W. (2015). The relationship among leisure attitude, satisfaction, and psychological wellbeing for college students. Journal of Physical Education and Sport, 15(1), 70-76.

Kim, Y. K., \& Trail, G. (2010). Constraints and motivators: A new model to explain sport consumer behavior. Journal of Sport Management, 24, 190-210.

Kraiger, K., Ford, J. K., \& Salas, E. (1993). Application of cognitive, skill-based, and affective theories of learning outcomes to new methods of training evaluation. Journal of Applied Psychology, 78(2), 311-328.

Loomis, J. (2016). The role of economic benefit measures in recreation planning and management. Journal of Park and Recreation Administration, Winter, 34(4), 106-108.

Mannell, R. C., \& Kleiber, D. A. (1997). A social psychology of leisure. State College, PA: Venture.

Müller, E., Gimpl, M. Poetzelsberger, B. Finkenzeller, T., \& Scheiber P. (2011). Salzburg Skiing for the Elderly Study: study design and intervention - health benefit of alpine skiing for elderly. Scandinavian Journal of Medicine and Science in Sports, 21 (Suppl. 1), 1-8.

Ostrom, T. M. (1969). The relationship between the affective, behavioral, and cognitive components of attitude. Journal of Experimental Social Psychology, 5(1), 13-30.

Pala A., Biner M., Öncen S., \& Kargün M. (2015). Analysis of the leisure attitudes of the football tennis players. International Sports, Exercise and Training Journal, 1(2), 77-82.

Ragheb, M. G., \& Beard, J. G. (1982). Measuring leisure attitude. Journal of Leisure Research, 2, 155-167.
Ragheb, M. G., \& Tate, R. L. (1993). A behavioural model of leisure participation, based on leisure attitude, motivation and satisfaction. Leisure Studies, 12, 61-70.

Robbins, S. (1994). Örgütsel davranışın temelleri (Çev: Sevgi Ayşe Öztürk) Eskişehir ETAM Basım Yayın.

Siegenthaler, K. L. \& O’Dell, I. (2000). Leisure attitude, leisure satisfaction, and perceived freedom in leisure within family dyads. Leisure Sciences, 22, 281-296.

Teixeira, A., \& Freire, T. (2013). The leisure attitude scale: psychometric properties of a short version for adolescents and young adults. Leisure/Loisir, 37(1), 57-67.

Türkiye İstatistik Kurumu (TUIK). (2016). 20152016 yllarına ilişkin, illere göre yaşam endeksi istatistikleri. Retrieved from http://www.tuik.gov.tr/ PreHaberBultenleri.do?id=24561

Uzun, N., \& Sağlam, N. (2006). Orta öğretim öğrencileri için çevresel tutum ölçeği geliştirme ve geçerliliği. Hacettepe Üniversitesi Ĕgitim Fakültesi Dergisi (H.U. Journal of Education), 30, 240-250.

Walker, G. J., Deng, J., \& Chapman, R. (2007b). Leisure attitudes: A follow-up study comparing Canadians, Chinese in Canada, and Mainland Chinese. World Leisure Journal, 49, 207-215.

Walker, G. J., Jackson, E. L., \& Deng, J. (2007a). Culture and leisure constraints: A comparison of Canadian and Mainland Chinese university students. Journal of Leisure Research, 39, 567-590.

Watson, J. F. (1996). The impact of leisure attitude and motivation on the physical recreation/leisure participation of college students. Unpublished doctoral thesis, Purdue University.
Corresponding author Süleyman Munusturlar Anadolu Universitesi Spor Bilimleri Fakultesi Iki Eylul Kampusu, 26555, Tepebasi, Eskisehir Turkey

Tel. 00905367361731

Email suleymanmunusturlar@anadolu.edu.tr suleyman.munusturlar@gmail.com 